\title{
Mediatization of Communication: from Concept to Theory
}

\author{
Irina A. Ushanova* \\ Novgorod State University \\ 41 B. St. Petersburgskaya Str., Veliky Novgorod, 173003, Russia
}

Received 08.08.2015, received in revised form 23.08.2015, accepted 25.09.2015

Mediatization, along with globalization, individualization and commercialization, is placed among major social processes that change culture and communication. The article sets forth polemics in the European academic community as to this phenomenon's definition. It examines the key approaches to the study of mediatization in humanities and social sciences and traces development of mediatization from the analytical concept to the theoretical basis. The main emphasis is laid on the communication mediatization theory by Friedrich Krotz and its implementation in the "Mediatized worlds" projects.

Keywords: mediatization, mediazation, mediation, medialization, mediatized worlds, media, communication.

DOI: 10.17516/1997-1370-2015-8-11-2703-2712.

Research area: philosophie, culture studies.

Over the past decade, the concept of mediatization became one of the central concepts in the international discussions on communication and media issues. Attention to the notion of mediatization was drawn back in 1995 by John B. Thompson who mentioned "mediazation of culture" by means of mass media (Thompson, 1995).

The interest of the European academic community regarding mediatization has been increasing ever since late 1990-s. Conceptual theoretical works and empirical researches of a more specialized nature were published in Germany, Great Britain, Norway and Denmark. Researchers from these countries are still actively cooperating with each other within international projects on this subject matter, thus reconfirming its current significance.

The first academic works on mediatization emerged in the political research field: in the late 1990-s, politics mediatization was discussed by Gianpietro Mazzoleni and Winfried Schulz (1999). The mid 2000-s witnessed a score of works concerning exploration of mediatization within various domains of culture and society, such as politics (Kepplinger, 2002; Vowe, 2006; Marcinkowski, Steiner, 2009; Strömbäck, Esser, 2009; Donges, 2008; Schulz, 2009), communication (Krotz, 2003, 2007; Hepp, 2009), religion and culture (Lundby, 2006; Hepp, Kroenert, 2009; Hjarvard 2008), sports (Dohle et al. 2009), and migration (Hepp et al. 2011).

(C) Siberian Federal University. All rights reserved

* Corresponding author E-mail address: ira29@mail.ru 
The works published in 2009 by two authors - namely, a Norwegian researcher Knut Lundby (Lundby, 2009) and a British academician Sonia Livingstone (Livingstone, 2009) - became landmarks for the new spin of European polemics over mediatization. In her foreword to the writings collection "Mediatization: Concepts, Changes, Consequences" and in her article "On the Mediation of Everything" Sonia Livingstone emphasizes that mediatization "refers to the meta process by which everyday practices and social relations are historically shaped by mediating technologies and media organizations" (Livingstone, 2009: X). Further, in the Introduction of the same collection, Knut Lundby anticipates the current studies of mediatization adding that processes of mediatization "affect almost all areas of social and cultural life in late modernity" (Lundby, 2009: 1). In their perception of mediatization both authors refer to Friedrich Krotz who can be rightfully named as one of the most reputable academicians in the media communication sphere in Germany and a father of the mediatization theory. Recognition of Krotz' approach at the international scale has changed the progress of mediatization studies by giving it more theoretical fundamentality. Re-consideration of the mediatization role from the viewpoint of Krotz theory can be found in nearly all relevant works of late years. Thus, in one of his recent articles, the British professor Nick Couldry analyzes main approaches to the mediatization studies and states therein that his starting-point for this new work "is the idea that mediatization is not a single transformative logic "within" media but a meta-category of social description that points to the changed dynamics and dimensionality of the (whole) social world in a media age" (Couldry, 2013, 6).

The essence of the approach by Friedrich Krotz to the mediatization phenomenon shall be examined in the third part of this work.

\section{On the definition of mediatization}

Active debate as to what should be meant by the term "mediatization" (Lundby, 2009; Hjarvard, 2004; Meyen, 2009; Schulz, 2004; Krotz, 2007; Hepp, 2011, 2014) is based, above all, on the terminological question: is it mediatization, mediazation, medialization, or mediation? In the German-speaking academic discourse, terms "Mediatisierung", "Medialisierung" and "Vermittlung" are correspondingly disputed. Considering the intensity of academic debates, let us concentrate on this matter for a while.

North American academicians describe the mediatization phenomenon without actually using the term. In the Great Britain where studies of mediatization are being more and more actively conducted in cooperation with the European colleagues, two main trends can be noted. Some academicians give preference to the term "mediation", although they use it to signify the same transformations as "mediatization" (Silverstone, 2007; Couldry, 2008). Others adhere to the expression "mediatization", which, in my opinion, is stipulated by this term's popularity in Scandinavian- and German-speaking academic community.

"Mediazation" by John B. Thompson (Thompson, 1995) should be mentioned separately, although content-wise it is close to the term "mediatization". Arguing on the connection between cultural changes and symbolic forms, J.B.Thompson means by "mediazation" such changes that have a clear institutional basis to support them, namely development of media organizations that have first emerged in the second half of the fifteenth century and have been developing their activity ever since (Thompson, 1995: 46). Thus, John B.Thompson dates the origins of the culture mediatization to the epoch of Gutenberg. 
Roger Silverstone takes up on Thompson's ideas, but adheres to the term "mediation" as a conceptual means for understanding the society and culture transformation (Silverstone, 2005: 189).

In his detailed contemplation of mediation in its relatedness to mediatization, Nick Couldry (Couldry, 2008: 376) admits that mediatization, as treated by Krotz, Schultz and Hjarvard, is targeting comprehension of various transformations of the social and cultural life. Nevertheless, personally he tends to prefer the term "mediation" while interpreting it in the course of reasoning by R.Silverstone (Couldry, 2008). In his later works, he elaborates once again that mediatization "is the term around which research within various national traditions about the widest consequences of media flows has come to converge: I will not recap here the debates that led to that terminological convergence. The real debate in any case is not about terminology, but about the type of explanation at which we are aiming" (Couldry, 2013: 4).

In the introduction mentioned above, Sonia Livingstone substantiates her choice of "mediatization" with reasoning that "mediation" is "too broad a term, refereeing not only to the socially constitutive importance of media but also to other mediations - transport, money, narrative, and, the paradigmatic case, language" (Livingstone, 2009: X).

Here she is seconded by Knut Lundby who also considers "mediation" too general a term. On the other hand, "mediation", to Lundby's opinion, is a broader and more general concept applied to acts and processes of communication with technical media that meaning-wise is close to German "Vermittlung" (Lundby, 2009: 13). It may affect communication and relations between the sender and the receiver, but in the long term, it shall not transform any institutional practices and modes of the social integration.
He counters the mediation supporters that mediatization points to societal changes in contemporary high modern societies and although processes of mediatization have roots in the technologies of the modern media, nevertheless, social processes shape mediatization" (Lundby, 2009: 4).

Answering the question as to how comprehensive the mediatization process is, Knut Lundby refers to the works by the Italian Gianpietro Mazzoleni and the Dane Stig Hjarvard. Mazzoleni, while perceiving mediatization in a broad sense as the media's growing influence on all spheres of the social life, draws attention to both mediatization of the society and mediatization within the society (Lundby, 2009:4).

Stig Hjarvard examines mediatization of the society and perceives there a dual process where the society submits more and more to the media and their logic or becomes dependent on them (Hjarvard, 2008: 113). The media are becoming an increasingly more independent institution within the society. Moreover, Stig Hjarvard highlights yet another material point: mediatization declares disappearance of reality. Mediatization should be interpreted as the capabilities enhancement for interaction in virtual spaces and differentiation of what people perceive as real (Hjarvard, 2008: 111).

The active controversy over the terms was typical for the German-speaking academic community as well. The main consideration was given, above all, to two options-"Medialisierung" and "Mediatisierung". Adepts of medialization are mostly researchers that deal with political communication (Donges, 2008; Meyen, 2009; Marcinkowski, Steiner, 2009; Schulz, 2011, 2013). Thus, Frank Marcinkowski and Andrian Steiner in their work "Was heist Medialisierung?" examine medialization of politics and specify that medialization is an analytical concept that should be treated as "ein überindividuelles 
Phänomen, das sich innerhalb von nichtmedialen Sozialsystemen (Funktionsbereichen wie Organisationen) ereignet, und zwar als Folge der Ausdifferenzierung eines eigenlogischen Mediensystems sowie des jeweils gegebenen Bedarfs an öffentlicher Aufmerksamkeit innerhalbseinerUmweltsysteme"(Marcinkowski, Steiner, 2009: 3). They emphasize this way that medialization is the consequence of not simply the media influence, but of the compound interaction of multiple media- and non-mediarelated causes.

While systemizing literature sources on the subject of medialization, Michael Meyen suggests a framework within which relevant empiric studies can be conducted (Meyen, 2009: 23-24). He justly reminds that the notion of "medialization" in historical and social sciences is interpreted differently. The understanding of medialization / mediatization depends on what is implicated under the term "media" and the communication theory subject, and a majority of researchers supports this thesis. The time period also depends on the notion of media and the study subject - that is, whether medialization is considered in the context of the entire humankind history span or just within the past few decades.

Regarding the choice between the two terms - mediatization and medialization Meyen adheres to the latter, the major reason being that "mediatization" has been long used in historical sciences with a different meaning. $\mathrm{He}$ considers the opinion of Steinmauer who uses both these terms: „"Mediatisierung” für den "immer dichteren technischen Vernetzungsgrad" und "Medialisierung" für die "Kontaminierung der Gesellschaft mit Medieninhalten"“ - being an extreme(Meyen, 2009: 26). Mediatization here pushes medialization and "die Ausbreitung medientypischer Verhaltens- und Denkweisen" forward (Steinmaurer, 2003: 107).
In the opinion of yet another adherer to "Medialisierung", W.Schulz, medialization means various changes in politics and their consequences (Schulz, 2011: 19). Politics belong to such spheres that are specifically affected by the media changes. The most prominent sign of medialization is the erasing of politics' borders via medial expansion (advancement) that is specified by technical innovations as well as medial, economic and organizational development in the media sector. However, in his interpretation of medialization, Schulz is very close to Krotz' version: "Medialisierung bezeichnet Aspekte des gesellschaftlichen Wandels infolge des Wandels der Medien" (Schulz, 2011: 30). This can be observed at both technical and content-wise level. Nevertheless, Schulz prefers "medialization" and, unlike Steinmauer, includes the technical aspect of the change, without burdening the notion with a negative connotation of "Kontaminierung". Same as Meyen, Schulz reminds us that mediatization has already been used in a different sense and context: "Die Form Medialisierung ist auch deshalb als fachspezifischer Terminus technicus besser als die Form Mediatisierung geeignet, weil sie exklusiver ist, also nicht in dieser oder ähnlicher Form in anderen fachlichen bzw. wissenschaftlichen Zusammenhängen vorkommt" (Schulz, 2011: 30). This refers to German mediatization, early 19th c. reorganization of political units that constituted the Holy Roman Empire. Moreover, in the opinion of Schulz, mediatization is phonetically similar to mediation - the way to settle a conflict with a help of a neutral intermediate.

Friedrich Krotz substantiates his rejection of "medialization" by stating that this term focuses the society's status as a media society and its consequences, while "mediatization" is a continuous changing process. In additions, he brings forward a practical reasoning: "Es soll hier betont werden, "die Form "Mediatisierung" 
vor allem deshalb benutzt wird, weil sie näher am alltäglichen Sprachgebrauch ist und weil sie in anderen Sprachen, insbesondere Englisch, leichter vermittelbar ist als "Medialisierung" (Krotz, 2007: 39). We shall look closer into Krotz' approach and his contribution into the development of the mediatization theory in the next part of the article.

To summarize intermediate outcomes, it should be noted that, despite the differences in definitions and terminological controversy, there is a number of common points in the approaches to the medialization / mediatization concept: it is admitted that these notions assume a social and cultural change, attribute the major role in this process to the media and thus compete with such processes as globalization, commercialization and individualization. The authors are unanimous in their statement that medialization / mediatization have become the key notions in the Communication Theory and Media Studies today.

\section{Mediatization of communication and mediatized world}

The works by F.Krotz concern, first of all, the observation of overall interrelation between the medial and communicative change, on one hand, and social and cultural changes, on the other hand. The key postulate that is presented by F.Krotz in his 2007 conceptual work "Mediatisierung: Fallstudien zum Wandel von Kommunikation" states that "es Sinn macht, den gewaltigen und rapiden Wandel von Medien und Kommunikation, den wir erleben und der uns als Menschen, Zivilbürger und als WissenschaftlerInnen herausfordert, mit dem Konzept der Mediatisierung zu fassen, um von daher einen ausbaufähigen Bezugspunkt für eine breit angelegte Kommunikationswissenschaft zu haben, die sich mit dem beschäftigt, was die Gesellschaft von ihr verlangt." (Krotz, 2007: 30).
Such approach is essential to ensure a prospective starting point for the communication theory out of it.

Gradually, Krotz expands the limits of the mediatization studies. Now the study focuses not only on the changes of the medial system, but also on the issues of communication changes and related: on the micro-level - changing people, their daily routine and their social relations; on the meso-level - changing parties, ventures, organizations and institutions; and on the macro-level - changing politics, economics, socialization, society, and culture (Krotz, 2012: 34-35, 37).

So, if we consider mediatization in a broad sense, as Krotz suggests, then it appears a long-term meta-process of changing media, their meaning, chances and challenges for people that are consequently entailed. This process progresses differently in different times, in various cultures and historical periods. "Als Prozess von Prozessen begleitet Mediatisierung die Menschheit und wird sie auch weiter begleiten, und in ihrem Verlauf werden sich auch Kultur als Netz von Sinnbildungsprozessen sowie Gesellschaft, Alltag und Identität etc. verändern. In dieser Form gewinnt der Mediatisierungsbegriff seine Relevanz, und dadurch wird das begriffliche Konzept Mediatisierung, seine Entwicklung und Anwendung für die Kommunikations- und die Sozialwissenschaften bedeutsam" (Krotz, 2012: 38).

This definition by F.Krotz raises questions of what should be understood as "media" so that the notion of mediatization is convincing (acceptable, credible) and exactly how mediatization functions.

As Andreas Hepp points out, the basis of contemplations by F.Krotz is formed by both narrow and broad notions of the media (Hepp, Hartmann 2010: 9). It is narrow, because it refers 
solely to the communication means - that is, to the communication's technical instruments, including all relevant forms of institutionalization and symbolic practices (e.g., money or a telescope are not media). At the same time, this notion is broad, because the technical communication means may be quite diverse (television, internet or robots as interactive media).

Fridrich Krotz characterized media in four views (Krotz, 2012: 42):

1. in the situational sense: the media as the "emotional experience space" for people (Erlebnisraum der Menschen) who use them this is their most important characteristic

2. in the situational sense: the media are complementary, they are a sort of "performance devices" (Inszenierungsapparate) that deal with specific meanings

3. in the structural sense: the media are diverse machinery

4. in the structural sense: the media are social institutions

Thus, media may be defined in the mediatization sense as a structure and a situation. They make communication possible and modify it.

But what can be subjected to mediatization? Answering this question, Krotz is categorical: "Das einzige, was mediatisiert sein kann, weil es das ist, was sich durch die Verwendung von Medien verändert, ist offensichtlich Kommunikation oder kommunikatives Handeln" (Krotz, 2012: 45). Taking this into consideration, one can talk now about mediatization of whatever else occurs by means of communication knowledge, relations, identity, organization, culture, society, politics, or reality. This is why mediatization should be understood as a change of communication or communicative action in the context of media changes. Krotz explains interrelation between media and mediatization on the following functional basis: mediatization of communication occurs owing to people that use specific techniques for their communicative actions and convert them into media by specific means and subsequently "konstituieren sie dann Kultur und Gesellschaft auf eine modifizierte Weise" (Krotz, 2012: 46). Then social and cultural processes that create a communicative need become determinative and, as a result, people use available technique by different methods or else a demand for new technique emerges.

The main ideas by F.Krotz are developed and implemented in the "Mediatisierte Welten" project that has been uniting academicians from Germany, Great Britain and Norway since 2009 until present days. The project is sponsored by the German scientific and research society (DFG). In the autumn of 2014, the thirds phase has started whose framework embodies 12 separate projects in German-speaking universities under the direction of F.Krotz.

While understanding mediatization as "die Durchdringung allerLebensbereichemit Medien", the project participants study the way everyday life and institutions, culture and societies change by means of more and more people communicating and acting by taking media into consideration (Mediatisierte Welten, 2014). Correspondingly, "mediatized worlds" concretize in the publicity, politics, everyday life, social relations, public institutions, etc. "Mediatized worlds" represent levels where mediatization becomes specific and may be empirically described (Mediatisierte Welten, 2012: 13).

The study of mediatization within the project framework can be linked to two points. First, mediatization is increasingly considered in its long-term historical prospect. Thus, the history of mankind is characterized by the increasing transfer from the direct mutual communication to the media-mediated one. With this transfer, the processes of the reality's communicative construction change. However, the mediatization 
concept covers not an individual example, but the long-term transformational process as such. Second, the notion of medialogic grows more significant. Mediatization is becoming a concept that embraces the interconnection of media and communication changes on one hand, and the culture and society change, on the other hand.

The issues of interrelations between mediatization, medialogic and medial culture are studied in details in the works by Andreas Hepp, a participant of "Mediatized worlds" project. Andreas Hepp has most ultimately demonstrated his understanding of the culture's mediatization in the work "Medienkultur: Die Kultur mediatisierter Welten". He suggests considering the wording "medial culture" a shortened notion for the mediatization of culture (Hepp, 2011: 34). In his understanding of mediatization, Hepp draws upon both Krotz and ideas of the aforementioned British sociologist J.B.Thompson.

In the definition issue, A.Hepp highlights two notions - mediatization and mediation (Vermittlung). However, he stipulates that he would not like to advance any arguments against Vermittlung as a key concept of the communication theory and Cultural Studies, as these positions are prominent and there are many arguments in favor of considering medial communication as a mediation process rather than mere information transfer (Hepp, 2011: 40). Therefore, A.Hepp does not contrapose these notions as conflicting. Turning to the ideas by J.Thompson, he points out that the mediatization process is more specific than mediation. As opposed to mediation that can describe each process of medial communication in its general characteristic, mediatization enables to understand something quite different that is based on the mediation of medial communication: "Mediatisierungsuchtzufassen,wiediehistorische Veränderung von Medienkommunikation mit weiteren Wandlungsprozessen zusammenhängt" (Hepp, 2011: 40). This way, Hepp manages to differentiate clearly these two notions while admitting a necessity of them both. Hepp rationalizes that mediatization is more than just a process of medial intercession of communication and its processes are considered on the level of further changes that may be accompanied by multiple mediations via medial communication.

While examining in detail the historical development of so-called media theoretical approaches (Mediumstheoretische Ansätze) and evolution theoretical approaches (evolutionstheoretische Ansätze) in his 2013 work "Mediatisierung von Kultur", A.Hepp arrives at the conclusion that the above mentioned approaches are insufficient for development of the related theory of an interrelation between mediacommunicative and socio-cultural changes. Mediatization has a potential for such change, as in the narrow sense the notion of mediatization is indicative of not a closed theory but a theoretical basis of media-communicative studies that are characterized by a specific approach to the phenomenon of media and communication: "Mediatisierung ist hier zuerst einmal ein offenes Konzept, um die Wechselbeziehung zwischen medienkommunikativem und soziokulturellem Wandel kritisch zu analysieren" (Hepp, 2013: 184).

Discussing the prospects of mediatization studies, A.Hepp suggests concretizing the notion of mediatization as an institutional and a social-and-constructivistic one. With the institutional notion of mediatization, the media are considered as more or less independent social institutions with their own rules and regularities. For this reason, mediatization includes adaptation of communication to "medialogic" in various spheres. In the broad sense, "medialogic" means "institutionalisierte Formate und Inszenierungsweisen von Medien, die auf der einen Seite nicht-mediale Repräsentationsformen aufgreifen, an die 
sich auf der anderen Seite aber nicht-mediale Akteure anpassen müssen, wenn sie in den Medien - hier verstanden als Massenmedien repräsentiert sein wollen" (Hepp, 2013: 186). With social and constructivistic understanding of mediatization, there is, above all, an analysis of the role of various media in the process of changing communicative construction of the social and cultural reality. The cornerstone here is the understanding of mediatization by F.Krotz. Such social and constructivistic reading of mediatization offers challenges for the historically-oriented study of contextualized changes of medial communication.

By uniting both trends, Hepp stresses one more important feature, namely, that the studies of mediatization should be conducted in the trans-medial synthetic perspective (Hepp, 2013: 187). In this context, the concept of "mediatisierte Welt" proves useful. In determination of the notion of "mediatized world" Hepp addresses the fundamental ideas: "mediatisierte Welten als spezifische "kleine Lebens-Welten" (Luckmann 1970) oder "soziale Welten" (Shibutani 1955; Strauss 1978), die in ihrer gegenwärtigen Form auf konstitutive Weise durch medienvermittelte Kommunikation artikuliert werden" (Hepp, 2013: 188). Thus, mediatized worlds are actually the everyday specifications of medial societies and cultures, so, if it turns out to be impossible to empirically study mediatization of the entire society, one can concentrate on studying the mediatized world of the school or private life - that is, to examine how various media have affected their communicative structures.

This particular understanding lies in the basis of the empiric studies conducted within the framework of the abovementioned project "Mediatisierte Welten". Subject-wise, the project is divided into three research areas: "action and interaction forms" (consideration, in the context of new media, of the forms and means of communication on which mediatized worlds are based), "networks" (study of professional and private networks created through media), and "contexts" (analysis of interrelation between mediatized worlds and social institutions). In the project's concept, the requirements to the mediatization theory are taken into consideration: the studies are conducted by trans-medial means, use innovative methods and enable to develop the integrative theory.

\section{Conclusion}

Summing up all of the above, we can state that mediatization studies intensify against the background of the growing importance of the medial communication for the culture and society formation. In the German, British and Scandinavian academic field, more and more unity is seen today in the approach to mediatization. The concept means a long-term overlapping process of social development, such as globalization or individualization. Within the mediatization studies, not only interrelations between medial and communicative changes are considered, but also the fact that together with them structures and processes of publicity, politics, organizations, everyday life, identity, and social relations advance.

The mediatization theory is still at its starting point. Nevertheless, we can already state that this concept itself has become an outcome of international mediatized communication in the academic community. In summer 2014, a multiauthor thesis "Mediatization of Communication" was published; it consists of 31 articles touching upon various aspects of communication mediatization. The list of authors includes such well-known researchers of mediatization as Sonia Livingstone, Nick Couldry, Stig Hjarvard, and participants of the "Mediatized worlds" project F.Krotz and A.Hepp. The title of Krotz' article can 
be taken as the slogan for the further advancement of the mediatization theory: "Mediatization as a mover in modernity: social and cultural change in the context of media change".

\section{References}

Couldry N. (2008) Mediatization or mediation? Alternative understandings of the emergent space of digital storytelling. New Media \& Society, 10(3), 373-391.

Couldry N. (2013) Mediatization and the Future of Field Theory. Communicative Figurations, Working Paper, (3), 2-18.

DongesP.MedialisierungpolitischerOrganisation.Wiesbaden, VS VerlagfürSozialwissenschaften, $2008,225 \mathrm{~S}$

Hepp A. Medienkultur: Die Kultur mediatisierter Welten. Wiesbaden: VS Verlag für Sozialwissenschaften, 2011, $174 \mathrm{~S}$.

Hepp A. Netzwerke, Kultur und Medientechnologie: Möglichkeiten einer kontextualisierten Netzkulturforschung. Digitale Medientechnologien. Wiesbaden: VS, 2011, S. 89-104.

Hepp A. Mediatisierung von Kultur: Mediengeschichte und der Wandel der kommunikativen Figurationen mediatisierter Welten. Transformationen des Kulturwelten: Prozesse des gegenwärtigen Kulturwandels. Wiesbaden: Springer Fachmedien, 2013, S. 179-199.

Hepp A., Hartmann M. Mediatisierung als Metaprozess: Der analytische Zugang von Friedrich

Hjarvard S. (2008) The mediatization of society. A theory of the media as agents of social and cultural change. Nordicom Review, 29 (2), p.105-134.

Krotz zur Mediatisierung der Alltagswelt. Die Mediatisierung der Alltagswelt. Wiesbaden: VS Verlag für Sozialwissenschaften, 2010, S. 9-20.

Krotz F. Mediatisierung: Fallstudien zum Wandel von Kommunikation. Wiesbaden: VS Verlag für Sozialwissenschaften, 2007. $332 \mathrm{~S}$.

Krotz F. Posttraditionale Vergemeinschaftung und mediatisierte Kommunikation. Posttraditionale Gemeinschaften. Wiesbaden: VS Verlag für Sozialwissenschaften, 2009, S. 151-169.

Krotz F. Rekonstruktion der Kommunikationswissenschaft: Soziales Individuum, Aktivität. Beziehung. Digitale Medientechnologien. Wiesbaden: VS, 2011, S. 27-51.

Krotz F. Vor der Entdeckung der Zentralperspektive zur Augmented Reality: wie Mediatisierung funktioniert. Mediatisierte Welten. Wiesbaden: VS Verlag für Sozialwissenschaften, 2012. S.28-55.

Krotz F. Aufwachsen in mediatisierten Welten. Medienwelten im Wandel: Kommunikationswissenschaftiche Positionen, Perspektiven und Konsequenzen. Wiesbaden: Springer Fachmedien, 2013, S. 39-53.

Livingstone S. Foreword: Coming to Terms with 'Mediatization'. Mediatization: Concepts, Changes, Consequences. New York: Peter Lang, 2009, p.IX-XI.

Livingstone S. (2009) On the Mediation of Everything. Journal of Communication, 59(1), 1-18.

Lundby K. "Mediatization" as Key. Mediatization: Concepts, Changes, Consequences. New York: Peter Lang, 2009, p.1-18.

Marcinkowski F., Steiner A. (2009) Was heist Medialisierung?, Available at: http://www.nccrdemocracy.uzh.ch/publications/workingpaper/pdf/WP29.pdf (accessed 5 April 2014).

Mazzoleni G. Mediatization of society. The international Encyclopedia of Communication. Malden: MA Blackwell, 2008. 
Mediatisierte Welten. Wiesbaden: VS Verlag für Sozialwissenschaften, 2012, 358 S.

Mediatisierte Welten (2014), Available at: http://www.mediatisiertewelten.de/startseite.html\#c8 (accessed 15 October 2014).

Mediatization of Communication. De Gruyter Mouton, 2014, 738 p.

Meyen M. (2009) Medialisierung. Medien \& Kommunikationswissenschaft, 57. Jahrgang, Heft 1. Hamburg, S. 23-38.

Schulz W. Politische Kommunikation. Wiesbaden: VS Verlag für Sozialwissenschaften, 2011, $245 \mathrm{~S}$.

Schulz W. Medialisierung - was war noch gleich die Frage? Realismus als Beruf: Beitraege zum Verhaeltnis von Medien und Wirklichkeit. Wiesbaden: Springer Fachmedien, 2013, S. 49-66.

Silverstone R. The sociology of mediation and communication. The Sage Handbook of Sociology. London: Sage, 2005.

Thompson J.B. The Media and Modernity: A Social Theory of the Media. Cambridge: Polity Press, 1995, $314 \mathrm{p}$.

\section{Медиатизация коммуникации:}

\section{от концепта к теории}

И.А. Ушанова Новгородский государственный университет Россия, 173003, Великий Новгород ул. Большая С.-Петербургская, 41

Медиатизаџию наряду с глобализаџией, индивидуализаџией и коммерииализаџией относят сегодня к основным социальным процессам, изменяющим культуру и коммуникацию. В статье представлена полемика в европейском научном сообществе по поводу дефиничии этого явления, рассматриваются основные подходы к изучению медиатизачии в гуманитарных и сочиальных науках и прослеживается развитие медиатизации - от аналитического концепта до теоретического основания. Основной акцент сделан на теории медиатизации коммуникации Фридриха Кротиа и ее реализачии в проектах «Медиатизированные миры»».

Ключевые слова: медиатизачия, медиазаџия, медиализация, медиаџия, медиатизированные миры, медиа, коммуникация.

Научная специальность: 09.00.00. - философские науки, 24.00.00-культурология. 